\title{
Analisis Nilai Hambatan Jenis Aluminium Berdasarkan Panjang Kawat Yang Berbeda
}

\author{
Elisa Kasli*, Via Risna Dewi, Hilda Mazlina \\ Program Studi Pendidikan Fisika, Universitas Syiah Kuala \\ *Email: kaslielisa@unsyiah.ac.id
}

Received: 11 Nopember 2019;

Accepted: 9 Juni 2020;

Published: 14 Juni 2020

DOI: http://dx.doi.org/10.29303/jpft.v6i1.1455

\begin{abstract}
This study aims to determine the value of aluminum specific resistance which is calculated based on Ohm's law. This research uses an experimental method. In this study, 4 experiments were carried out with different lengths of wire. The first experiment used a wire length of $0.05 \mathrm{~m}$, the second experiment used a wire length of $0.1 \mathrm{~m}$, the third experiment used a wire length of $0.15 \mathrm{~m}$, and the fourth experiment used a wire length of $0.2 \mathrm{~m}$. The results of the study showed that the wire length of $0.05 \mathrm{~m}$ obtained the value of the type resistance of $2.7 \times 10^{-3} \mathrm{\Omega m}$, the length of the wire of $0.1 \mathrm{~m}$ obtained the value of the type resistance of $2.7 \times 10^{-3} \Omega \mathrm{m}$, the length wire of $0.15 \mathrm{~m}$ obtained type resistance value of $2.7 \times 10^{-3} \mathrm{\Omega m}$ and at a wire length of $0.2 \mathrm{~m}$ obtained type resistance value of $2.7 \times 10^{-3} \mathrm{\Omega m}$. Thus, it can be concluded that the change value of aluminum types will be the same value if the wire material used is also the same value.
\end{abstract}

Keywords: Ohm's Law; Hambatan Jenis; Aluminium.

\section{PENDAHULUAN}

Daya listrik menjadi suatu hal yang tidak terlepas dari dampak perkembangan zaman dan menjadi salah satu kebutuhan pokok untuk manusia saat ini. Hal ini disebabkan karena semakin banyak aktivitas manusia yang memerlukan energi listrik. Daerah pedesaan saja membutuhkan listrik, apalagi pada kota - kota besar yang sudah menjadi kawasan industri, pertokoan, perbelanjaan, kebutuhan pokok dan lainlainnya (Tenda \& Tumaliang, 2016). Dalam kehidupan sehari-hari, kita dapat mendengar radio, menonton televisi, menggunakan kulkas, kipas angin, setrikaan dan lain-lain. Penggunaan alat-alat tersebut memerlukan listrik. Arus listrik terjadi karena adanya perpindahan muatan - muatan listrik.

Muatan listrik dalam jumlah tertentu yang menembus suatu penampang dari suatu penghantar dalam satuan waktu tertentu disebut sebagai kuat arus listrik. Mudah tidaknya suatu arus mengalir pada suatu penghantar dinyatakan dalam Hukum Ohm. Hasil percobaan George Simon Ohm (1787 - 1854) yang menunjukkan adanya hubungan antara arus, beda potensial dan hambatan yaitu : kuat arus yang mengalir pada suatu penghantar berbanding lurus dengan beda potensial antar kedua ujung penghantar tersebut dan berbanding terbalik dengan hambatannya. Secara matematis ditulis :

$$
\mathrm{I}=\frac{V}{R}
$$

Keterangan:

$\mathrm{I}=$ kuat arus (Ampere)

$\mathrm{V}=$ beda potensial (Volt)

$\mathrm{R}=$ hambatan $(\mathrm{Ohm})$

Berdasarkan eksperimen yang telah dilakukan oleh George Simon Ohm, perubahan hambatan kawat (R) suatu penghantar sangat bergantung pada tiga hal yaitu hambatan jenis kawat $(\rho)$, panjang kawat (L), dan luas penampang kawat (A). Secara matematis ditulis persamaannya :

Keterangan:

$$
\rho=\frac{R A}{L}
$$

$\mathrm{R}=$ Hambatan kawat $(\Omega)$

$\rho=$ Hambatan jenis $(\Omega \mathrm{m})$

$\mathrm{L}=$ Panjang kawat $(\mathrm{m})$

$A=$ Luas penampang $\left(\mathrm{m}^{2}\right)$ 
Setiap bahan atau material, baik itu logam maupun non logam mempunyai hambatan tertentu. Perbedaan hambatan pada masing - masing bahan atau material inilah yang disebut dengan hambatan jenis (Edi, 2007). Resistansi suatu material bergantung pada panjang, luas penampang lintang, dan tipe material. Untuk material material yang mematuhi hukum Ohm resistansi tidak bergantung pada arus yaitu perbandingan V/I tidak bergantung pada I. Material seperti ini, seperti pada kebanyakan logam, disebut material ohmik. Untuk material ohmik, tegangan jatuh pada suatu segmen sebanding dengan arus. Untuk material non Ohmik, perbandingan V/I bergantung pada arus, sehingga arus tidak sebanding dengan beda potensial. Untuk non Ohmik, resistansi R bergantung pada arus I yang menunjukkan beda potensial $\mathrm{V}$ terhadap arus I (Wahyudi, 2017).

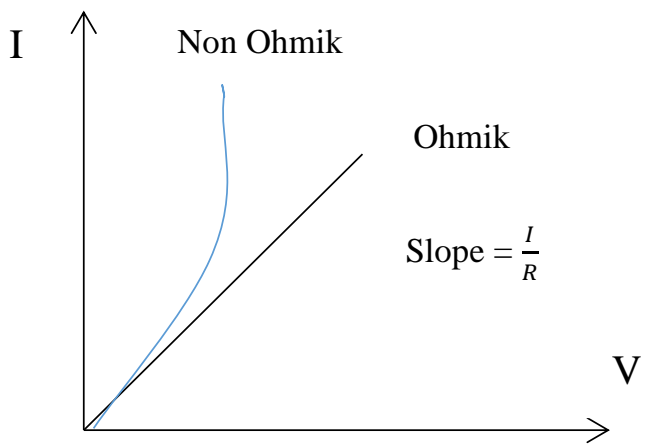

Gambar 1. Kurva I-V untuk Hambatan (Sumber: Sari \& Pradita, 2018)

Sugiarta, IBK (2011) dengan penelitian, mengungkapkan bahwa dari sekian banyak bahan penghantar yang ada, tembaga dan aluminium adalah dua bahan pengantar yang memenuhi persyaratan baik secara teknis maupun secara ekonomis untuk difungsikan sebagai pengantar dalam sistem transmisi, distribusi dan instalasi tenaga listrik (Roben et al. 2017). Kawat penghantar berfungsi untuk mengalirkan arus listrik dari suatu tempat ke tempat yang lain. Jenis kawat penghantar yang biasa digunakan pada saluran transmisi adalah tembaga dengan konduktivitas $100 \%$ (CU $100 \%$ ), atau aluminium dengan konduktivitas $61 \%$ (AL $61 \%$ ). Kawat penghantar tembaga memiliki kelemahan yaitu untuk besar tahanan yang sama, tembaga lebih berat dari aluminium, dan juga lebih mahal. Oleh karena itu kawat aluminium telah menggantikan kedudukan tembaga. Kawat dengan bahan konduktor untuk saluran transmisi tegangan tinggi selalu tanpa pelindung / isolasi kawat. Ini hanya kawat berbahan tembaga atau aluminium dengan inti baja yang terbentang untuk mengalirkan arus listrik (Tenda \& Tumaliang, 2016).

Campuran aluminium digunakan untuk memperbesar kuat tarik dari kawat aluminium. Untuk saluran - saluran transmisi tegangan tinggi, dimana jarak menara / tiang berjauhan mencapai ratusan meter, maka dibutuhkan kuat tarik yang lebih tinggi, untuk itu digunakan kawat penghantar ACSR (Aluminium Conductor Steel Reinforced), yaitu kawat penghantar aluminium berinti kawat baja (Setiyo, 2008).

Aluminium merupakan logam ringan yang mempunyai sifat ketahanan korosi yang baik dan juga hantaran listrik dan panas yang baik dan sifat - sifat yang baik lainnya sebagai sifat logam. Material ini dipergunakan di dalam bidang yang luas bukan hanya peralatan rumah tangga tapi juga dipakai untuk keperluan material pesawat terbang, mobil, kapal laut, dan lain - lain. Aluminium sangat berperan penting dalam berbagai bidang aplikasi karena memiliki sifat - sifat menarik dan beraneka ragam. Sifat - sifat tersebut membuat aluminium menjadi logam yang sangat sesuai dan ekonomis untuk banyak aplikasi dan telah menjadikan aluminium sebagai logam yang paling banyak digunakan kedua setelah baja. Berikut adalah aplikasi aluminium secara umum : 
Tabel 1. Aplikasi Aluminium diberbagai Bidang

\begin{tabular}{cc}
\hline Aplikasi Penggunaan & Persentasi \\
\hline Industri Konstruksi & $15 \%$ \\
Aplikasi Listrik & $15 \%$ \\
Industri Otomatif / & $25 \%$ \\
Transportasi & \\
Industri Manufaktur & $25 \%$ \\
dan Pengemasan & \\
Lainnya & $20 \%$ \\
\hline
\end{tabular}

Salah satu sifat dari aluminium yaitu konduktivitas listrik tinggi, dimana konduktivitas listrik dari aluminium dua kali lebih besar dari pada tembaga dengan perbandingan berat yang sama. Sehingga sangat cocok digunakan dalam kabel transmisi listrik (Fahmi, 2015).

Selain itu, kelebihan dari pada aluminium juga ekonomis, dimana biaya proses pembuatan, pemasangan, dan perawatan aluminium lebih murah dan tahan lama (Kawulur et al. 2013). Sehingga dengan mengetahui sifat - sifat maupun kelebihan pada aluminium, kedepannya alat - alat kelistrikan dapat menggunakan bahan aluminium. Selama ini eksperimen yang pernah dilakukan yaitu untuk mengetahui nilai hambatan jenis tembaga maupun nikrom. Namun mahasiswa belum pernah mencoba melakukan eksperimen menggunakan variabel berupa hambatan jenis aluminium. Oleh karena itu, dilakukan penelitian yang bertujuan untuk mengetahui nilai hambatan jenis aluminium menggunakan rangkaian hukum ohm.

\section{METODE PENELITIAN}

Penelitian ini menggunakan metode eksperimen dengan variabel bebas yaitu aluminium dan variabel terikatnya adalah nilai hambatan jenis. Penelitian ini dilakukan selama 2 (dua) hari di Laboraturium Fisika pada tanggal 17 September 2019 dan 18 september 2019, dengan alat dan bahan yang digunakan yaitu 1 (satu) buah catu daya, 1 (satu) multimeter, 1 (satu) papan rangkaian, 7 (tujuh) jembatan penghubung, 4 (empat) kabel penghubung, 2 (dua) penjepit, 4 (empat) kawat aluminium, 1 (satu) penggaris, dan 1 (satu) jangka sorong.

Proses menentukan nilai hambatan jenis aluminium dilakukan dengan menggunakan rangkaian hukum ohm dengan panjang kawat yang berbeda-beda yaitu $5 \mathrm{~cm}, 10 \mathrm{~cm}, 15 \mathrm{~cm}$, dan $20 \mathrm{~cm}$ yang diukur dengan mnggunakan penggaris. Langkah berikutnya yaitu ukur diameter aluminium menggunakan jangka sorong, kemudian rangkailah alat pada papan rangkaian dan hubungkan jembatan dan kabel penghubung pada rangkaian tersebut. Setelah itu jepit kawat aluminium yang sudah dipotong pada penjepit. Langkah berikutnya hidupkan catu daya dan multimeter serta amati multimeter untuk melihat nilai beda potensial dan kuat arus listrik. Kemudian catat hasilnya dan ulangi langkah sebelumnya untuk percobaan selanjutnya. Berikut gambar 1 dan gambar 2 yang menunjukkan panjang kawat yang berbeda dan rangkaian percobaan.

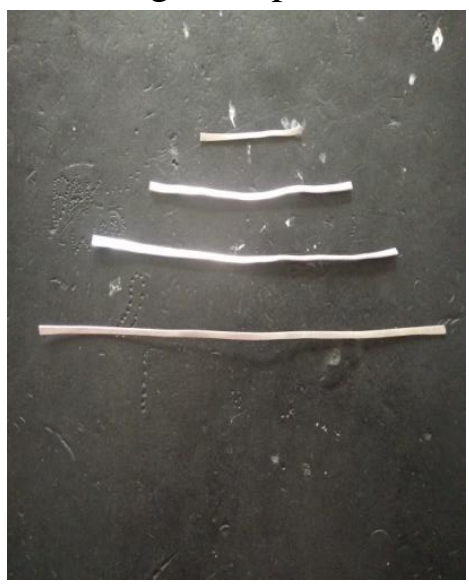

Gambar 1. Panjang kawat yang berbeda yaitu $5 \mathrm{~cm}, 10 \mathrm{~cm}, 15 \mathrm{~cm}$ dan $20 \mathrm{~cm}$ 


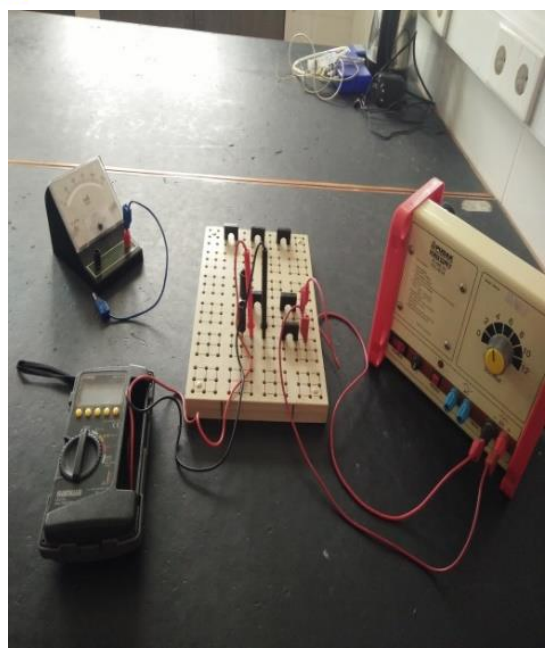

Gambar 2. Rangkaian percobaan menghitung nilai hambatan jenis pada aluminium

\section{HASIL DAN PEMBAHASAN}

Penelitian ini bertujuan untuk mengetahui nilai hambatan jenis aluminium dengan menggunakan rangkaian hukum ohm. Data penelitian ini diambil setelah melakukan percobaan sebanyak 4 kali dengan menggunakan panjang kawat yang berbeda. Data hasil percobaan disajikan dalam tabel berikut :

Tabel 2. Hasil Pengamatan

\begin{tabular}{ccccc}
\hline No. & $\begin{array}{l}\mathbf{V} \\
(\mathbf{v o l t})\end{array}$ & $\mathbf{I}(\mathbf{A})$ & $\mathbf{L}(\mathbf{m})$ & $\boldsymbol{\rho}(\mathbf{\Omega m})$ \\
\hline 1 & 1 & 0,9 & 0,05 & $2,7 \times 10^{-3}$ \\
2 & 1,3 & 1,21 & 0,1 & $2,7 \times 10^{-3}$ \\
3 & 1,46 & 1,32 & 0,15 & $2,7 \times 10^{-3}$ \\
4 & 1,56 & 1,4 & 2,0 & $2,7 \times 10^{-3}$ \\
\hline
\end{tabular}

Berdasarkan percobaan yang telah dilakukan, ada empat perlakuan yang diberikan, yang pertama percobaan 1 pada penggunaan panjang kawat sebesar $0,05 \mathrm{~m}$ dapat menghasilkan tegangan sebesar 1 volt dan kuat arus listrik sebesar 0,9 A. Pada penggunaan panjang kawat sebesar $0,1 \mathrm{~m}$ dapat menghasilkan tegangan sebesar 1,3 volt dan kuat arus listrik sebesar 1,21 A. Pada penggunaan panjang kawat sebesar 0,15 $\mathrm{m}$ dapat menghasilkan tegangan sebesar 1,46 volt dan kuat arus listrik sebesar 1,32 A dan pada penggunaan panjang kawat sebesar 0,2 $\mathrm{m}$ dapat menghasilkan tegangan sebesar 1,56 volt dan kuat arus listrik sebesar 1,4 A. Hasil dari penelitian menunjukkan bahwa pada panjang kawat sebesar $0,05 \mathrm{~m}$ didapatkan nilai hambatan jenis sebesar 2,7 x $10^{-3} \Omega$ m,pada panjang kawat sebesar $0,1 \mathrm{~m}$ didapatkan nilai hambatan jenis sebesar 2,7 x $10^{-3} \Omega \mathrm{m}$, pada panjang kawat sebesar 0,15 $\mathrm{m}$ didapatkan nilai hambatan jenis sebesar $2,7 \times 10^{-3} \Omega \mathrm{m}$ dan pada panjang kawat sebesar $0,2 \mathrm{~m}$ didapatkan nilai hambatan jenis sebesar $2,7 \times 10^{-3} \Omega \mathrm{m}$. Dengan demikian dapat diperoleh dari data hasil penelitian bahwa nilai hambatan jenis aluminium akan bernilai sama jika bahan kawat yang digunakan juga sama. Sesuai dengan pernyatan Rahmatika et al. (2019) “ nilai resistivitas suatu kawat akan bernilai tetap walaupun diameter dari kawat tersebut berbeda". Konduktivitas suatu kawat penghantar bergantung juga pada kemurnian dari logam yang digunakan, konduktivitas akan semakin besar apabila kemurnian logam bertambah tinggi dan berkurang apabila campurannya bertambah.

\section{PENUTUP}

Adapun kesimpulan dari penelitian ini yaitu : pada panjang kawat sebesar $0,05 \mathrm{~m}$ didapatkan nilai hambatan jenis sebesar 2,7 x $10^{-3} \Omega$ m,pada panjang kawat sebesar $0,1 \mathrm{~m}$ didapatkan nilai hambatan jenis sebesar 2,7 x $10^{-3} \Omega \mathrm{m}$, pada panjang kawat sebesar 0,15 $\mathrm{m}$ didapatkan nilai hambatan jenis sebesar $2,7 \times 10^{-3} \Omega \mathrm{m}$ dan pada panjang kawat sebesar 0,2 $\mathrm{m}$ didapatkan nilai hambatan jenis sebesar $2,7 \quad \mathrm{x} \quad 10^{-3} \quad \Omega \mathrm{m} \quad$ yang menunjukkan nilai hambatan jenis aluminium akan bernilai sama jika bahan kawat yang digunakan juga sama.

Pada penelitian ini hanya dibatasi menentukan nilai hambatan jenis aluminium dengan panjang kawat yang berbeda namun tidak menentukan nilai hambatan jenis aluminium dengan diameter yang berbeda. 
Oleh karena itu, dibutuhkan penelitian lebih lanjut mengenai nilai hambatan jenis aluminium dengan diameter yang berbeda.

\section{REFERENSI}

Edi, I. (2007). Fisika kelas X untuk SMA dan $M A$. Klaten: PT.intan pariwara.

Fahmi, H. (2015). Analisa Kekerasan dan Fracture Toughness Alumina Diperkuat Serbuk Aluminium dan Tembaga. Jurnal Teknik Mesin (JTM), 5(1).

Kawulur, C. L., Patras, L. S., Tuegeh, M., \& Lisi, F. (2013). Aplikasi Perhitungan Biaya Pokok Penyediaan Tenaga Listrik di Sulawesi Utara Sub Sistem Transmisi. Jurnal Teknik Elektro dan Komputer, 2(2).

Rahmatika, A., Ibrahim, S., Hersaputri, M., \& Aprilia, E. (2019). Studi pengaruh variasi kuat arus terhadap sifat mekanik hasil Pengelasan GTAW alumunium 1050 dengan filler ER 4043. Jurnal POLIMESIN, 17(1), 4754.

Roben, D., Bagia, I. N., \& Manesi, D. (2017). Studi Tentang Penggunaan Aluminium Foil Sebagai Penghantar Arus Pada Output Koil Sepeda Motor Honda 110cc. Komodo Jurnal Pendidikan Teknik Mesin, 1(2), 119126.

Sari, K. D., \& Pradita, A. P. (2018). Implementasi Model Pembelajaran Discovery Learning Menggunakan Media Spreadsheet Pada Materi Hukum Ohm Untuk Meningkatkan HOTS Pada Peserta Didik In Prosiding SNPS (Seminar Nasional Pendidikan Sains) (pp. 116-122).

Setiyo, M. (2008). Menjadi Mekanik Spesialis Kelistrikan Sepeda Motor. Bandung: Alfabeta.

Sugiarta, Ida Bagus Ketut. (2011). Kajian Teknis Dan Ekonomis Penggunaan Kabel Tembaga Dibandingkan Dengan Kabel Aluminium Pada System Instalasi Dan Distribusi Kabel
Power Di Power House W Hotel Retreat and SpaBali. Jurnal Logic, II(3), 119-126.

Tenda, N., \& Tumaliang, H. (2016). Penyusutan Daya Listrik Pada Penyulang Jaringan Transmisi Isimu Marisa. Jurnal Teknik Elektro dan Komputer, 5(1), 75-83.

Wahyudi, W. (2017). Analisis Hasil Belajar Mahasiswa pada Pokok Bahasan Hukum Ohm dan Kirchoff dalam Matakuliah Elektronika Dasar I. Jurnal Pendidikan Fisika dan Teknologi, 1(2), 129-134. 